\title{
Effectiveness of Different Final Irrigation Protocols in Removing Debris in Flattened Root Canals
}

\author{
Michele Regina NADALIN ${ }^{1}$ \\ Danyel Elias da Cruz PEREZ ${ }^{2}$ \\ Luiz Pascoal VANSAN ${ }^{1}$ \\ Cristina PASCHOALATO ${ }^{1}$ \\ Manoel Damião SOUSA-NETO ${ }^{3}$ \\ Paulo César SAQUY ${ }^{3}$
}

\begin{abstract}
${ }^{1}$ Department of Endodontics, Dental School, University of Ribeirão Preto, Ribeirão Preto, SP, Brazil ${ }^{2}$ Department of Oral Pathology, Dental School, University of Ribeirão Preto, Ribeirão Preto, SP, Brazil ${ }^{3}$ Department of Restorative Dentistry, Dental School, University of São Paulo, Ribeirão Preto, SP, Brazil
\end{abstract}

\begin{abstract}
This study evaluated in vitro the capacity of debris removal from the apical third of flattened root canals, using different final irrigation protocols. Thirty human mandibular central incisors with a mesiodistal flattened root were prepared using rotary instrumentation by Endo-Flare 25.12 and Hero 642 30.06, 35.02, 40.02 files, irrigated with $2 \mathrm{~mL}$ of $1 \% \mathrm{NaOCl}$ after each file. The specimens were randomly distributed into 5 groups according to the final irrigation of root canals: Group I: $10 \mathrm{~mL}$ of distilled water (control), Group II: $10 \mathrm{~mL}$ of $1 \% \mathrm{NaOCl}$ for 8 min, Group III: $2 \mathrm{~mL}$ of $1 \% \mathrm{NaOCl}$ for $2 \mathrm{~min}$ (repeated 4 times), Group IV: $10 \mathrm{~mL}$ of $2.5 \% \mathrm{NaOCl}$ for $8 \mathrm{~min}$, and Group V: $10 \mathrm{~mL}$ of $2.5 \%$ $\mathrm{NaOCl}$ for $2 \mathrm{~min}$ (repeated 4 times). The apical thirds of the specimens were subjected to histological processing and 6- $\mu \mathrm{m}$ cross-sections were obtained and stained with hematoxylin-eosin. The specimens were examined under optical microscopy at $\times 40$ magnification and the images were subjected to morphometric analysis using the Scion image-analysis software. The total area of root canal and the area with debris were measured in square millimeters. Analysis of variance showed no statistically significant difference ( $\mathrm{p}>0.05)$ among the groups GI ( 2.39 $\pm 3.59)$, GII $(2.91 \pm 2.21)$, GIII $(0.73 \pm 1.36)$, GIV $(0.95 \pm 0.84)$ and GV $(0.51 \pm 0.22)$. In conclusion, the final irrigation protocols evaluated in this study using the Luer syringe presented similar performance in the removal of debris from the apical third of flattened root canals.
\end{abstract}

Key Words: Endodontics, instrumentation, methods, sodium hypochlorite.

\section{INTRODUCTION}

Biomechanical preparation is the stage of endodontic treatment that aims at cleaning, disinfecting and shaping the root canals in order to eliminate bacteria and their irritating products, degenerated pulp tissue and contaminated dentin $(1,2)$, thereby, creating an adequate surgical space for filling the root canal system.

The use of nickel-titanium instruments during biomechanical preparation creates an apical stop with a larger diameter and minimum apical transportation, when compared with the stainless steel instruments. Thus, a larger amount of pulp tissue, contaminated dentin and microorganisms are removed. Furthermore, wider apical preparation facilitates the disinfection process because a larger volume of irrigant solution can act in this region (3). However, nickel-titanium instruments are not effective for cleaning flattened root canals, or those in which the canal shape does not allow instrumentation $(4,5)$. In these situations, irrigant solutions may assume fundamental importance in biomechanical preparation (6).

Among these solutions advised for biomechanical preparation, sodium hypochlorite, at different concentrations, is the most used due to its properties of clarification, organic tissue dissolution, saponification, transformation of amines into chloramines, deodorization and antimicrobial action $(7,8)$.

In addition to the physicochemical properties inherent to each irrigant solution, constant renewal of the solution during canal preparation by various irrigation- 
aspiration cycles, avoids saturation, precipitation of particles, and favors the removal of debris in suspension inside the root canal (9). On this respect, some methods have been used for irrigating root canal systems such as the Luer-Lock syringe and irrigation needles of different calibers (10), the Quantec-E system, in which irrigation occurs concomitantly with rotary instrumentation (11), the NiviTip Fx system (12), the ultrasound irrigation system $(13,14)$ and the electrochemical activation of cationic or anionic solutions (15).

Other factors related to irrigation can influence the effectiveness of cleaning the root canal system, such as the volume and pressure of the solution inside the canal (16), the caliber and penetration depth of the irrigation needle $(17,18)$, the time that the solution remains inside the root canal (19), the contact area and heating promoted by solution that might increase the organic tissue dissolution (8).

Due to the limitations of instrumentation methods and the difficulty of completely cleaning root canals, it is necessary to develop alternative procedures to optimize the cleaning process. Therefore, the aim of this study was to assess in vitro by histologic and morphometric analysis, the capacity of debris removal from apical third of flattened root canals using different final irrigation protocols with the Luer-Lock syringe.

\section{MATERIAL AND METHODS}

Thirty human mandibular central incisors extracted for periodontal reasons were used in this study. All teeth had a mesiodistal flattened root with a single canal, confirmed by radiographic exam. The teeth showed completely formed roots and apical foramen with standard diameter of a size 15 file K-file (DentsplyMaillefer, Ballaigues, Switzerland), and were maintained in $0.1 \%$ thymol solution at $4^{\circ} \mathrm{C}$ before use.

Conventional access was performed using a size $10 \mathrm{~K}$-file (Dentsply-Maillefer), which was introduced into each canal until it appeared at the apical foramen. The working length was determined by subtracting 1 $\mathrm{mm}$ from this measurement. The teeth were prepared by the crown-down technique, using rotary instrumentation (Endo Plus electric motor; Driller, São Paulo, SP, Brazil) with Endo-Flare (25.12) and Hero (642 30.06, 35.02, 40.02) files (Micro-Méga, Besançon, France). Initially, the cervical third from the root canal was prepared with Endo-Flare 25.12 file, followed by irrigation with $2 \mathrm{~mL}$ of $1 \% \mathrm{NaOCl}$. After enlargement of the cervical third, the middle third was instrumented with 30.06 file of Hero 642 system and the apical with 35.02 and 40.02 files. Irrigation with $2 \mathrm{~mL}$ of $1 \% \mathrm{NaOCl}$ was performed after each file, using a Luer Lock syringe (Omega, São Paulo, SP, Brazil).

The specimens were randomly distributed into 5 groups according to the volume, concentration and irrigation time of the $\mathrm{NaOCl}$ solution used in the final irrigation: Group I: $10 \mathrm{~mL}$ of distilled water (control); Group II: $10 \mathrm{~mL}$ of $1 \% \mathrm{NaOCl}$, which remained into root canals for $8 \mathrm{~min}$; Group III: $2 \mathrm{~mL}$ of $1 \% \mathrm{NaOCl}$, which remained into root canals for $2 \mathrm{~min}$ (the procedure was repeated 4 times, totalizing $8 \mathrm{~min}$ ). In Group IV, it was used $10 \mathrm{~mL}$ of $2.5 \% \mathrm{NaOCl}$, which remained into root canals for $8 \mathrm{~min}$; and in Group V, $10 \mathrm{~mL}$ of $2.5 \% \mathrm{NaOCl}$, remaining into root canals for $2 \mathrm{~min}$ (the procedure was repeated 4 times, totalizing $8 \mathrm{~min}$ ).

For the irrigation procedure, 27-gauge needles (Becton Dickinson, Juiz de Fora, MG, Brazil) attached to $10 \mathrm{~mL}$ Luer-Lock syringes (Omega) were used. In order to remove the solutions, the teeth were washed with $2 \mathrm{~mL}$ of saline solution followed by drying of the canals with absorbent paper points (Dentsply Ind. e Com. Ltda., Petrópolis, RJ, Brazil).

After biomechanical preparation, the specimens were immersed in $10 \%$ buffered formalin for $24 \mathrm{~h}$, decalcified in $10 \%$ trichloroacetic acid for 10 days and afterward, washed in water for $12 \mathrm{~h}$. The apical thirds of each root were sectioned and removed, subjected to routine histological processing and embedded in paraffin. Serial $6-\mu \mathrm{m}$-thick cross-sections were obtained from paraffin-embedded blocks and stained with hematoxylin-eosin. Five cross-sections were randomly obtained from each apical third (30 sections for each group). For the morphometric analysis, the histological slides were examined with an optical microscope at $\times 40$ magnification, which was coupled to a computer where the images were recorded with the Adobe Premier 5.1 software (Adobe Systems Incorporated, San Jose, CA, USA). Using Scion image-analysis software for Windows (beta 4.02 version; Scion Corporation, Frederick, MD, USA), the total canal area and the area with debris were measured in square millimeters. In each crosssection, the percentage of debris in the root canal after biomechanical preparation was calculated using the 2 measurements, total canal area and area with debris. The amount of debris in each specimen was obtained by mean percentage of 10 histological slides. For statistical 
analysis, the results were subjected to analysis of variance, considering a 5\% significance level.

\section{RESULTS}

The morphometric analysis revealed a smaller percentage of debris (mean \pm standard deviation) in the root canals from Group V $(0.51 \pm 0.22)$, followed by Group III ( $0.73 \pm 1.36)$, Group IV (0.95 \pm 0.84$)$, Group II $(2.91 \pm 2.21)$ and Group I (3.41 \pm 3.59$)$. However, the comparative analysis between Group I (control) and Groups II, III, IV and V did not show statistically significant difference $(\mathrm{p}=0.055)$.

\section{DISCUSSION}

New instruments and techniques for root canal irrigation have been developed and tested in order to achieve the absence of debris and smear layer after biomechanical preparation. However, it is difficult to completely clean root canals, especially when dealing with accentuated flattened apical regions $(4,5)$.

In this study, the results did not show significant difference among the final irrigation protocols with the Luer-Lock syringe for debris removal from the apical third of flattened root canals. Factors related to the physical and mechanical action of biomechanical preparation should be considered to understand these findings. The first refers to the volume of the solution used during irrigation, which was the same for all groups. According to Scelza et al. (7), the volume is more important than the type of the solution, due to the mechanical action created by the flux and reflux of the solution inside the canal, removing debris left in suspension after biomechanical procedures. The second factor concerns the caliber of the irrigation needle (27 gauge), which was also the same for all groups, thereby, providing the same pressure, irrigation time and hydrodynamic flux of the solution inside the canals. Boutsioukis et al. (16) reported that needles with thinner diameters require more force to dispense the solution, which results in an increase in its pressure inside the root canal, thus, favoring the debridement of the region. Indeed, some authors verified that the efficacy of the irrigant solution depends on the action of the irrigation needle, being greater when $1 \mathrm{~mm}$ from working length were used compared with $5 \mathrm{~mm}$ (18).

Finally, it is relevant to consider that biomechanical preparation with the $\mathrm{Ni}$-Ti system allows a larger surgical diameter with minimum deviation. According to Albrecht et al. (17), root canal preparation done with instruments of larger conicity in the cervical and middle region permits an effective flux and reflux of the solution in the apical region, allowing the needle to achieve deeper areas into the canal and favoring the debridement. These concepts were observed in the methodology of the present study, in which the teeth were prepared with the 25.12 EndoFlare instrument and the surgical diameter at the working length was equivalent to a size 40 instrument. Moreover, apical preparation in flattened canals with the 40.02-Hero instrument promotes a greater removal of dentin and debris (20), generally leaving only the "polar areas" or isthmus without instrumentation.

As regards the chemical action of the solution, it was observed that an increase in the concentration did not contribute to root canal cleaning in the final irrigation. This probably occurred because in this situation, the function of the solution would only be entrainment, since the water behaved in the same way as the $\mathrm{NaOCl}$ at $1 \%$ and at $2.5 \%$ in debris removal. It should be emphasized that during the rotary instrumentation, $2 \mathrm{~mL}$ of $1 \% \mathrm{NaOCl}$ was used in every change of the instrument, allowing the chemical action of the solution.

According to Spanó et al. (8), the dissolution capacity of dental tissue by $\mathrm{NaOCl}$ is directly related to the mechanical agitation, volume, temperature and concentration of the solution, and with the amount of the solution remained in contact with the organic tissue. The chemical action of the $\mathrm{NaOCl}$ on the organic tissues occurs by the formation of hypochlorous acid, which reacts with the insoluble proteins, forming soluble products. This reaction can be accentuated by continuous flux and larger amount of solution, which would provide the effective removal of superficial debris and prolongation of the chemical activity of the solution $(7,9)$. According to Baratto-Filho et al. (6), rotary instrumentation combined with $\mathrm{NaOCl}$ irrigation at different concentrations between each instrument evidenced greater debris removal for the $5 \% \mathrm{NaOCl}$ solution when compared to the $0.5 \%$ solution, whereas in the present study, the increased concentration in the final irrigation did not contribute to canal cleaning. On the other hand, other authors observed that in the final irrigation, the $\mathrm{NaOCl}$ energized with ultrasound contributed to debris removal, in comparison to distilled water energized by ultrasound as well (13).

This study demonstrated the importance of 
investigating the irrigation technique in root canal cleaning. Therefore, with optimization of instrumentation by rotary system, irrigation assumes an important role in removing suspended debris from the root canal system and areas where the instrument did not reach.

Based on the employed methodology and the obtained results, it may be concluded that there was no significant difference among the tested irrigation protocols with the Luer-Lock syringe in debris removal from the apical thirds of flattened root canals. Furthermore, none of the different final irrigation protocols were completely efficient in cleaning the apical portion of the canals. Sodium hypochlorite solutions at $1 \%$ and $2.5 \%$ present similar performance in removing debris from the apical third of the flattened canals.

\section{RESUMO}

Este estudo avaliou, in vitro, a capacidade de remoção de debris do terço apical de canais radiculares achatados, usando diferentes protocolos de irrigação final. Trinta incisivos centrais mandibulares humanos com a raiz mésio-distal achatada foram preparados usando instrumento rotatório Endo-Flare 25.12 e limas Hero 64230.06 , $35.02,40.02$, irrigadas com $2 \mathrm{ml}$ de $\mathrm{NaOCl} 1 \%$ após cada lima. Os espécimes foram aleatoriamente distribuídos em cinco grupos de acordo com a irrigação final dos canais radiculares: Grupo I: 10 $\mathrm{mL}$ de água destilada (controle), Grupo II: $10 \mathrm{~mL}$ de $\mathrm{NaOCl}$ a $1 \%$ por $8 \mathrm{~min}$, Grupo III: $2 \mathrm{~mL}$ de $\mathrm{NaOCl}$ a $1 \%$ por 2 min (repetidos 4 vezes), Grupo IV: $10 \mathrm{~mL}$ de $\mathrm{NaOCl} 2,5 \%$ por 8 min e Grupo V: 10 $\mathrm{mL}$ de $\mathrm{NaOCl} 2,5 \%$ por $2 \mathrm{~min}$ (repetido 4 vezes). Os terços apicais dos espécimes foram submetidos a processamento histológico de rotina e cortes transversais com $6 \mu \mathrm{m}$ de espessura foram obtidos e corados com hematoxilina e eosina. Os espécimes foram analisados em microscopia óptica com aumento final de $40 \mathrm{X}$ e as imagens submetidas à análise morfométrica com a utilização do software Scion Image. A análise de variância evidenciou não haver diferença estatística $(\mathrm{p}>0,05)$ entre os grupos GI $(2,39 \pm 3,59)$, GII $(2,91 \pm$ $2,21)$, GIII $(0,73 \pm 1,36)$, GIV $(0,95 \pm 0,84)$ e GV $(0,51 \pm 0,22)$. Conclui-se que os protocolos de irrigação final utilizando a seringa Luer apresentaram comportamentos semelhantes na remoção de debris do terço apical de canais radiculares achatados.

\section{REFERENCES}

1. Baratto-Filho F, Leonardi DP, Zielak JC, Vanni JR, Sayão-Maia SM, Sousa-Neto MD. Influence of ProTaper finishing files and sodium hypochlorite on cleaning and shaping of mandibular central incisors-a histological analysis. J Appl Oral Sci 2009;17:229-233.

2. Williamson AE, Sandor AJ, Justman BC. A comparison of three nickel titanium rotary systems, EndoSequence, ProTaper universal, and profile GT, for canal-cleaning ability. J Endod 2009;35:107-109.

3. Rödig T, Hülsmann M, Kahlmeier C. Comparison of root canal preparation with two rotary NiTi-instruments: ProFile-.04 and GT Rotary. Int Endod J 2007;40:553-562.
4. Fariniuk LF, Baratto-Filho F, Cruz-Filho AM, Sousa-Neto MD. Histologic analysis of the cleaning capacity of mechanical endodontic instruments activated by the ENDOflash system. J Endod 2003;29:651-653.

5. Rödig T, Hülsmann M, Mühge M, Schäfers F. Quality of preparation of oval distal root canals in mandibular molars using nickeltitanium instruments. Int Endod J 2002;35:919-928.

6. Baratto-Filho F, Carvalho Jr. JR, Fariniuk LF, Sousa-Neto MD, Pécora JD, Cruz-Filho AM. Morphometric analysis of the effectiveness of different concentrations of sodium hypochlorite associated with rotary instrumentation for root canal cleaning. Braz Dent J 2004;15:36-40.

7. Scelza MFZ, Antoniazzi JH, Scelza P. Efficacy of final irrigation - a scanning electron microscopic evaluation. J Endod 2000;26:355-358.

8. Spanó JCE, Barbin EL, Santos TC, Guimarães LF, Pécora JD. Solvent action of sodium hypochlorite on bovine pulp and physicochemical properties of resulting liquid. Braz Dent J 2002;12:154-179.

9. Van der Sluis LW, Gambarini G, Wu MK, Wesselink PR. The influence of volume, type of irrigant and flushing method on removing artificially placed dentine debris from the apical root canal during passive ultrasonic irrigation. Int Endod J 2006;39:472-476.

10. Cameron JA. The choice of irrigant during hand instrumentation and ultrasonic irrigation of the root canal: a scanning electron microscopic study. Aust Dent J 1995;40:85-90.

11. Setlock J, Fayad MI, Begole E, Bruzick M. Evaluation of canal cleanliness and smear layer removal after the use of the QuantecE irrigation system and syringe: a comparative scanning electron microscope study. Oral Surg Oral Med Oral Pathol Oral Radiol Endod 2003;96:614-617.

12. Al-Hadlaq SM, Al-Turaiki SA, Al-Sulami U, Saad AY. Efficacy of a new brush-covered irrigation needle in removing root canal debris: a scanning electron microscopic study. J Endod 2006;32:1181-1184.

13. Passarinho-Neto JG, Marchesan MA, Ferreira RB, Silva RG, Silva-Sousa YTC, Sousa-Neto MD. In vitro evaluation of endodontic debris removal as obtained by rotary instrumentation coupled with ultrasonic irrigation. Aust Endod J 2006;32:123-128.

14. Van der Sluis LW, Wu MK, Wesselink PR. The evaluation of removal of calcium hydroxide paste from an artificial standardized groove in the apical root canal using different irrigation methodologies. Int Endod J 2007;40:52-57.

15. Qing Y, Akita Y, Kawano S, Kawazu S, Yoshida T, Sekine I. Cleaning efficacy and dentin micro-hardness after root canal irrigation with a strong acid electrolytic water. J Endod 2006;32:1102-1106.

16. Boutsioukis C, Lambrianidis C, Kastrinakis E, Bekiaroglou P. Mensurement of pressure and flow rates during irrigation of a root canal ex vivo with three endodontic needles. Int Endod J 2007;40:504-513.

17. Albrecht LJ, Baumgartner JC, Marshall JG. Evaluation of apical debris removal using various sizes and tapers of ProFile GT files. J Endod 2004;30:425-428.

18. Sedgley CM, Nagel AC, Hall D, Applegate B. Influence of irrigant needle depth in removing bioluminescent bacteria inoculated into instrumented root canals using real-time imaging in vitro. Int Endod J 2005;38:97-104.

19. Gambarini G. Shaping and cleaning the root canal system: a scanning electron microscopic evaluation of a new instrumentation and irrigation technique. J Endod 1999;25:800-803.

20. Usman N, Baumgartner JC, Marshall JG. Influence of instrument size on root canal debridement. J Endod 2004;30:110-112.

Accepted February 14, 2009 